\title{
A NEW LIVER FUNCTION TURBIDITY TEST
}

\author{
BY
}

\author{
H. N. ANTONIADES
}

From the Biochemical Laboratory of the Evangelismos Hospital, Athens, Greece

(RECEIVED FOR PUBLICATION JULY 15, 1952)

The various liver flocculation tests proposed in recent years by several investigators cannot be considered as specific, hence clinicians tend to use many of them simultaneously. Obviously, the simplicity and the rapidity with which any one of these tests can be performed are essential advantages. The following new liver function turbidity test is simple and rapid, and is more sensitive than the other known tests.

In 1949 for the first time it was observed that che addition of diethylbarbituric acid to human blood serum in a test-tube produced a characteristic turbidity which was dense in serum from patients with hepatic diseases. Later it was determined that a saturated solution of diethylbarbituric acid produced turbidity with serum both from patients with hepatic diseases and from healthy individuals. However, with a solution of $0.44 \mathrm{~g}$. per $1,000 \mathrm{ml}$. of distilled water, a dense turbidity was obtained with serum from clinical cases of liver damage and slight or no turbidity in normals. The addition of $0.05 \mathrm{ml}$. of blood serum taken from clinically positive cases to $4 \mathrm{ml}$. of the diluted solution of diethylbarbituric acid produced almost immediately a dense turbidity, which, at the peak of the reaction 20 minutes later, was compared with the nephelometric scale of Kingsbury-Clark. During this primary procedure it was observed that when the mixture of serum and diethylbarbituric acid in the test-tube was heated for one minute in a water-bath the turbidity obtained was dense and more stable than without heating. It remained unchanged for over two weeks.

\section{Method}

Preparation of the Reagent.-A solution of $0.44 \mathrm{~g}$. of pure diethylbarbituric acid (Merck, Darmstadt) in $1.000 \mathrm{ml}$. of distilled water is heated in a flask to boiling point, and then cooled at room temperature before use. The solution is stable, and, if properly stored. can be used for a long period.

Procedure.-To $4 \mathrm{ml}$. of this solution in a test-tube $0.05 \mathrm{ml}$. of the serum under examination is added. The mixture is shaken gently. and then heated for one minute in a boiling water-bath. making sure that the test-tube is thoroughly immersed. After heating, the mixture is again shaken, and the resulting turbidity is compared visually with the standard scale of testtubes of an equal diameter. The reading may be helped by observing through the tubes a black line traced on a white paper. As a standard scale, the turbidity tubes used for measuring albumin in urine may be used, although in our experiments we have preferred a modification made with agar and mastic of the Kingsbury-Clark scale.

Values of Turbidity.-For the determination of the values of turbidity the following criteria were laid down: negative $(-)$, the sample which corresponded to less than $50 \mathrm{mg} . \%$ of albumin, and positive $(+)$. that corresponding to more than $50 \mathrm{mg}$. $\%$ of albumin. The reading of the turbidity is as follows:

$$
\begin{array}{rrrl}
50 & \text { mg. } & \text { gave } & ( \pm) \\
60 & . . & , & (+) \\
80 & . . & . . & (++) \\
110 & . . & ., & (+++) \\
130 & . . & ., & (++++)
\end{array}
$$

For the successful performance of the reaction and the avoidance of errors the following points should be observed. (1) The measurements should be as accurate as possible. (2) The serum must be placed in the test-tube without blowing through the pipette, because the carbon dioxide will render the test positive. (3) The test-tubes must be dry and scrupulously clean. (4) The serum for examination should be fresh: a serum which has undergone haemolysis or has been inactivated should be discarded. (5) Blood should preferably be collected in the morning before any food is taken.

\section{Clinical Observations}

One thousand six hundred and ninety-two clinical cases were investigated using the proposed new reaction together with the thymol reaction of Maclagan (Maclagan, 1944a and b, 1947, 1948 : Maclagan and Bunn, 1947 : Maclagan, Martin, and Lunnon, 1952) for comparison. The cases were mainly in-patients in the Evangelismos Hospital, the Greek Red Cross Hospital, the Children's Hospital, the Hippocration Hospital, the Cancer Institute, and the Athens Hospital for Infectious Diseases. 
TABLE I

COMPARISON OF CASES PROVED POSITIVE BY DIETHYLBARBITURIC ACID AND THYMOL TESTS

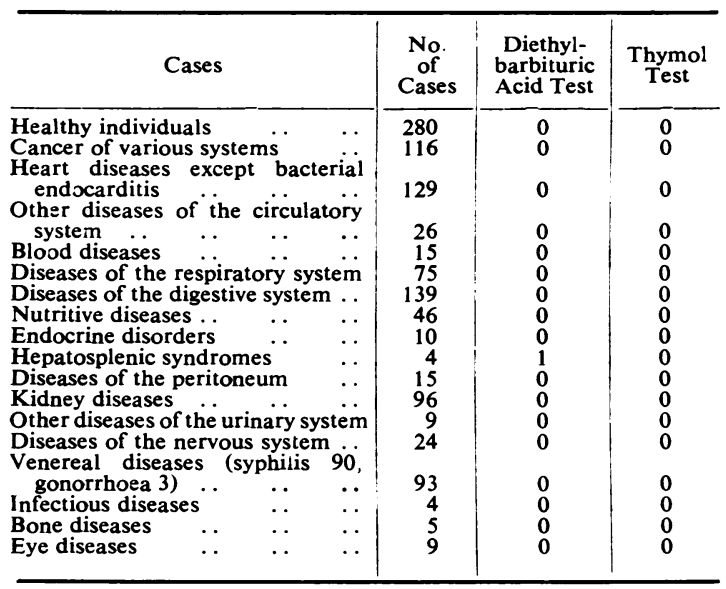

It should be stated here that in these investigations only those cases of which the clinical diagnosis could be confirmed by the laboratory findings have been included. In Table I the laboratory findings of normal individuals and of patients with a negative reaction as compared with the findings of the thymol reaction are set out. Observation of these cases indicated that in normal individuals the diethylbarbituric acid test was negative with a turbidity ranging between the absolutely clear and below $50 \mathrm{mg} . \%$. The same readings were obtained with the thymol reaction. Under the classification of normal individuals are included 280 persons with no damage whatever to the hepatic cell.

In 464 cases with some sort of hepatic disease (Table II), the diethylbarbituric acid test and the thymol test were both performed and the following results by classification of disease obtained.

Acute Icterogenic Hepatitis.-In this classification are included the jaundice due to bacteria, viruses, or a toxic cause, namely, (a) infectious jaundice (streptococcal, spirochaetal, etc.), (b) in-

TABLE II

COMPARISON OF POSITIVE RESULTS BY DIETHYLBARBITURIC AND THYMOL TESTS IN HEPATOPATHIES

\begin{tabular}{|c|c|c|c|}
\hline Cases & $\begin{array}{l}\text { No. } \\
\text { of } \\
\text { Cases }\end{array}$ & $\begin{array}{l}\text { Diethyl- } \\
\text { barbituric } \\
\text { Acid Test }\end{array}$ & $\begin{array}{c}\text { Thymol } \\
\text { Test }\end{array}$ \\
\hline 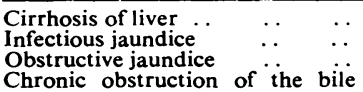 & $\begin{array}{r}107 \\
87 \\
73\end{array}$ & $\begin{array}{r}107 \\
87 \\
0\end{array}$ & $\begin{array}{r}74 \\
87 \\
0\end{array}$ \\
\hline 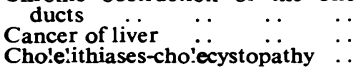 & $\begin{array}{l}24 \\
81 \\
92\end{array}$ & $\begin{array}{r}24 \\
0 \\
0\end{array}$ & $\begin{array}{r}15 \\
0 \\
0\end{array}$ \\
\hline
\end{tabular}

fectious epidemic and catarrhal jaundice, and (c) toxic jaundice.

In all 87 investigated cases the readings were positive for both the diethylbarbituric acid and the thymol reactions. There was a similarity in the two reactions with the diethylbarbituric test stronger during the acute stage of disease. Both reactions remained positive throughout the course of illness until regression.

Obstructive Jaundice.-In 73 cases of jaundice from obstruction of the bile ducts the diethylbarbituric acid test was negative. Obviously, therefore, the test can be used with great advantage in the differential diagnosis of obstructive jaundice from infectious jaundice and cirrhosis of the liver.

In cases of chronic obstruction of the bile ducts, in which there is degenerative damage to the hepatic cell, the test becomes positive and sometimes strongly positive (marked hepatic insufficiency). Twenty-four such cases for which the turbidity test was positive were studied, whereas the thymol test was found positive in only 15 of the 24 cases. In 10 of the cases the damage to the hepatic cell was proved by laparotomy.

We believe that with the proposed method it will be possible to assess the function of the hepatic cell in patients with chronic obstruction of the bile ducts.

Cirrhosis of the Liver.-The diethylbarbituric acid test is of more particular importance in the siudy of cases of cirrhosis of the liver. In this category both types of cirrhosis are included. In all 107 studied cases of cirrhosis the diethylbarbituric acid test was positive or strongly positive, and in some instances the test gave a strong flocculation. The test became positive from the pre-ascitic stage until death. The various degrees of turbidity obtained throughout the illness can be used as a prognostic guide. On the other hand, the thymol test was found positive in only 74 of the 107 cases.

Cancer of the Liver.-In 81 cases of cancer of liver the diethylbarbituric acid test and the thymol test were both found negative.

Cholelithiasis-cholecystopathy.-In 92 cases of cholelithiasis and cholecystopathy the turbidity test and the thymol test were found negative.

Cardiac Liver.-When the liver becomes enlarged due to backward venous pressure in heart diseases the diethylbarbituric acid test becomes positive in most instances. Of 34 studied cases of cardiac liver, the turbidity test was positive in $\mathbf{3 0}$ and the thymol test in 27 . In five cases of endo- 
carditis lenta the diethylbarbituric acid test was strongly positive, whereas the thymol test was positive in only four. A strong positive reaction was obtained in nine cases of syphilitic hepatitis. In 22 cases of amoebiasis with enlargement of the liver the diethylbarbituric acid test was slightly to definitely positive. In eight other cases of amoebiasis without evidence of hepatic involvement the reaction was found positive in five cases only.

\section{The Diethylbarbituric Acid Test in Other Diseases}

Apart from the hepatopathies, the test was found positive in kala-azar and leprosy.

Kala-azar.-Due to the rare occurrence of this disease the test was performed in only seven cases of kala-azar, patients in the Children's Hospital, Athens. The patients were aged from 1 to 12 years, and gave positive reactions for leishmaniasis. The striking characteristic in our experience with these cases of kala-azar was that both reactions were strongly positive and that, instead of turbidity, a very strong flocculation was obtained. This can be amply justified by the fact that in the serum of patients with kala-azar there is a great increase of globulin.

Leprosy.-Investigation on cases of leprosy presented a special interest, for the diethylbarbituric acid test was found to be positive, even in cases where the Hansen reaction was negative.

\section{Discussion}

The addition of serum to the solution of diethylbarbituric acid causes turbidity, which is due to the precipitation of a certain fraction of the proteins in the serum. The lipids do not take part in the reaction. A serum thinned with ether gives stronger turbidity because it is enriched with proteins. In 17 cases with a positive reaction the serum proteins (Table III) were determined according to the micro-Kjeldahl method (Koch and McMeekin, 1924).

From a study of these results it could be said that the turbidity found in positive cases is due to an increase in the globulin, or its fraction or fractions. These fractions are precipitated in the acid medium of the solution of the diethylbarbituric acid at $p \mathbf{H} 6.5$. Similar results were also obtained with other diluted solutions of acids. We have experimented, for instance, with buffered solutions of citric acid and sodium citrate without diethylbarbituric acid at a $p H$ between 5 and 6.5 . To $4 \mathrm{ml}$. of the buffered solution $0.05 \mathrm{ml}$. of blood serum was added, as in the case of the test with diethylbarbituric acid. In clinically positive cases
TABLE III

ANALYSIS OF SERUM PROTEINS IN DIETHYLBARBITURIC ACID TEST

\begin{tabular}{|c|c|c|c|c|c|}
\hline $\begin{array}{c}\text { Case } \\
\text { No. }\end{array}$ & $\begin{array}{c}\text { Reaction of } \\
\text { Diethyl- } \\
\text { barbituric } \\
\text { Acid }\end{array}$ & $\begin{array}{c}\text { Albumin } \\
\text { (Normal } \\
4-5 \cdot 5)\end{array}$ & $\begin{array}{c}\text { Globulin } \\
\text { (Normal } \\
1 \cdot 5-3)\end{array}$ & $\begin{array}{c}\text { Total } \\
\text { Proteins } \\
\text { (Normal } \\
6 \cdot 0-8 \cdot 0)\end{array}$ & Diagnosis \\
\hline$\frac{1}{2}$ & $\begin{array}{l}(-) \\
(++)\end{array}$ & $\begin{array}{l}4 \cdot 7 \\
2 \cdot 4\end{array}$ & $\begin{array}{l}1.6 \\
3.8\end{array}$ & $\begin{array}{l}6 \cdot 3 \\
6 \cdot 2\end{array}$ & $\begin{array}{l}\text { Normal } \\
\text { Cirrhosis } \\
\text { liver }\end{array}$ \\
\hline $\begin{array}{l}3 \\
4 \\
5 \\
6 \\
7 \\
8 \\
9\end{array}$ & $\begin{array}{l}(+++) \\
(+++) \\
(++) \\
(++++) \\
(++) \\
\text { Flocculation } \\
(++++)\end{array}$ & $\begin{array}{l}2 \cdot 6 \\
3 \cdot 9 \\
3 \cdot 3 \\
3 \cdot 1 \\
3 \cdot 1 \\
2 \cdot 1 \\
1 \cdot 6\end{array}$ & $\begin{array}{l}4 \cdot 2 \\
4 \cdot 0 \\
2 \cdot 9 \\
4 \cdot 3 \\
2 \cdot 9 \\
4 \cdot 6 \\
5 \cdot 7\end{array}$ & $\begin{array}{l}6 \cdot 8 \\
7 \cdot 9 \\
6 \cdot 2 \\
7 \cdot 4 \\
6 \cdot 0 \\
6 \cdot 7 \\
7 \cdot 3\end{array}$ & $\begin{array}{rr}, ", & ,, \\
, ", & , " \\
\text { Infectious } \\
\text {,", }\end{array}$ \\
\hline $\begin{array}{l}10 \\
11 \\
12 \\
13 \\
14 \\
15\end{array}$ & $\begin{array}{l}(++) \\
(++) \\
(+++) \\
(+++) \\
(++) \\
(++)\end{array}$ & $\begin{array}{l}2 \cdot 8 \\
3 \cdot 2 \\
3 \cdot 4 \\
3 \cdot 0 \\
3 \cdot 6 \\
3 \cdot 3\end{array}$ & $\begin{array}{l}4 \cdot 2 \\
3 \cdot 3 \\
3 \cdot 5 \\
4 \cdot 3 \\
3 \cdot 3 \\
3 \cdot 2 \\
\cdot 2\end{array}$ & $\begin{array}{l}7 \cdot 0 \\
6 \cdot 5 \\
6 \cdot 9 \\
7 \cdot 3 \\
6 \cdot 9 \\
6 \cdot 5\end{array}$ & $\begin{array}{c}\text {," ", } \\
\text { ", ", } \\
\text { Hepatitis" } \\
\text { Amoebic }\end{array}$ \\
\hline 16 & $\begin{array}{l}\text { Strong floc- } \\
\text { culation }\end{array}$ & $1 \cdot 0$ & $5 \cdot 0$ & $6 \cdot 0$ & \multirow{2}{*}{$\begin{array}{l}\text { Hepatitis" } \\
\text { Amoebic } \\
\text { hepatitis } \\
\text { Kala-azar } \\
\begin{array}{c}\text { Normal } \\
\text { individual }\end{array}\end{array}$} \\
\hline 17 & $(-)$ & $5 \cdot 1$ & $2 \cdot 2$ & $7 \cdot 3$ & \\
\hline
\end{tabular}

of hepatic diseases no turbidity was obtained with the buffered solution until the mixture was heated for one minute in a water-bath. A control test with diethylbarbituric acid, however, gave a turbidity in the solution before heating. Nevertheless, buffered solutions diluted five- or ten-foldwith distilled water on the addition of serum gave a turbidity before heating, its density depending on the degree of dilution. Following this observation we experimented with various organic acids in low dilutions. The readings were similar to the results obtained with our solution of diethylbarbituric acid.

These observations lead to the conclusion that the $p \mathrm{H}$, the concentration of the reagent, the temperature, the time of heating, and, particularly, the composition of proteins in the blood serum, are the factors which determine the degree of precipitation of the globulin fraction. It is likely that the appearance of a positive turbidity is due to the balance of the serum proteins being upset and probably to an increased globulin fraction.

In using a solution of diethylbarbituric acid of $0.44 \mathrm{~g} . \%$ we obtained the right medium for the precipitation of the globulin fraction, which obviously . is increased in cases with a positive reaction. By means of the proposed nephelometric determination, the diagnostic value of our method can be evaluated.

\section{Summary}

A new precipitation method for evaluating hepatic insufficiency and other diseases is proposed using a solution of diethylbarbituric acid. 
The reaction has been studied in 1,692 cases and the results compared with those of the thymol test. It was found to give positive readings in cirrhosis of the liver, infectious hepatitis, chronic obstruction of the bile ducts (when the disease causes a degenerative change in the hepatic cell), endocarditis lenta, cardiac liver, amoebic hepatitis, kala-azar, and leprosy. It gave negative readings in cases of cancer of the liver, obstructive jaundice, chololithiasis, cholocystopathy, and various other conditions.

The proposed reaction was found more sensitive than the thymol reaction, which occasionally gave negative readings where the diethylbarbituric acid test was positive.

The reagent used is simple and stable, with a minimum time required for the performance of the test and obtaining readings.
The turbidity which appears in the positive reactions is due to an imbalance between albumin and globulin in the blood cell, more specifically to the increase of globulin, a fraction of which is precipitated by the adjusted concentration in the solution of diethylbarbituric acid.

I have pleasure in recording my indebtedness to Professor G. Joakimoglou for his helpful guidance.

\section{REFERENCES}

Koch, F. C., and McMeekin, T. L. (1924). J. Amer. chem. Soc., 46, 2066.

Maclagan, N. F. (1944a). Brit. J. exp. Path., 25, 15.

(1944b). Ibid., 25, 234.

(1947). Brit. med. J., 2, 197.

(1948). Ibid., 2, 892.

and Bunn, D. (1947). Biochem. J., 41, 580.

Martin, N. H., and Lunnon, J. B. (1952). Journal of Clinical Pathology, 5, 1. 